\title{
The Effects of Male and Female Cohabitation on Academic Performance of Nigeria Tertiary Institutions Students: A Case of Rufus Giwa Polytechnic, Owo, Ondo State, Nigeria
}

\section{* Nurudeen Saka-Olokungboye ${ }^{1}$; Ebunoluwa Hope Ehinola ${ }^{2}$; Joseph Olanrenwaju Ilugbami ${ }^{3}$;Olaleke Olateru - Olagbegi ${ }^{4}$}

${ }^{1}$ Department of Social Sciences, ${ }^{2}$ Department of Cooperative Economics and Management, ${ }^{3}$ Department of Social Development, ${ }^{4}$ Department of Public Administration.

1,2,3,4, Rufus Giwa Polytechnic, P.M.B 1019, Owo, Ondo State, Nigeria

Citation: Nurudeen Saka-Olokungboye, Ebunoluwa Hope Ehinola, Joseph Olanrenwaju Ilugbami, Olaleke Olateru - Olagbegi (2022) The Effects of Male and Female Cohabitation on Academic Performance of Nigeria Tertiary Institutions Students: A Case of Rufus Giwa Polytechnic, Owo, Ondo State, Nigeria, International Journal of Education, Learning and Development, Vol. 10, No.1, pp.44-61

\begin{abstract}
Cohabitation has gained notoriety in Nigeria tertiary institutions and has continued to attract scholarly attention in recent time. This deviant behavior comes in various guises and aliases among Nigeria tertiary institutions students where the menace is widely spread. It is commonly referred to as 'campus marriage', 'couple's life', campus coupling', marrying for marriage' etc, a nomenclature invented to give this deviant and wholesome act an acceptable norm amongst youths in Nigeria tertiary institutions. This study, therefore, investigates the effects of cohabitation on Academic performance of students of Rufus Giwa Polytechnic, Owo, Ondo State, Nigeria. The study adopted an exploratory design-method and a total of 360 National Diploma (ND) and Higher National Diploma (HND) students were randomly sampled from the six faculties of the polytechnic. Rational choice theory was employed to explain why individual is more likely to undertake actions that they perceive to be best option and one that would immensely be to their own advantage. The data collected were analyzed using descriptive statistic-percentages and frequency. The study reveals that $72.8 \%$ of the respondents live outside the institution due to shortage of hostel accommodation, thus they cohabit. The study found out that $92.45 \%$ of the respondents agreed that cohabitation increases risk of unwanted pregnancy among cohabiting students especially females, which may affect their academic performances. Also, $86.2 \%$ agreed that frequent and unrestrained sexual activities could affect academic performance of cohabiting students. Based on the findings, it was therefore, recommended that Management of the institution should provide adequate hostel accommodation for students, parents and guardians should pay frequent unscheduled visit to their children in school and regular sensitization programme should be done for students on the danger of cohabitation by the Polytechnic management.
\end{abstract}

KEYWORDS: cohabitation, tertiary institution, academic performance, Rufus Giwa polytechnic, social malaise.

@ECRTD-UK https://www.eajournals.org/

https://doi.org/10.37745/ijeld.2013 


\section{INTRODUCTION}

The $21^{\text {st }}$ century has witnessed a social malaise that has gained notoriety in Nigeria Tertiary Institutions. This deviant behavior comes in various guises and aliases among Nigeria Tertiary Institutions Students where the menace is widely spread. It is commonly referred to as " Campus Marriage', 'Couples life' 'Campus Coupling', 'marrying for marriage' etc, a nomenclature invented to give this deviant and wholesome act an acceptable norm amongst youths in Nigeria tertiary institutions (Adeniyi, 2019, p.12; Augustinah et al., 2018, p.28).

Cohabitation, a process where two people who are emotionally, romantically and sexually intimate choose to live together without making formal commitment of marriage (Adeniyi, 2019 , p.12) has become a prevalent, popular and alternative lifestyle among young men and women in Nigeria tertiary institutions. Abdullahi (2013) cited in Adeniyi (2019, p.10) stated that cohabitation can be encapsulated as both a status and a process, and it is also an alternative type of housing for at least one of the cohabiters, and it is not a new phenomenon. Augustinah, Bola-Margaret and Louis-Omolayo (2018, p.28) observed that cohabitation pertain to either heterosexual or same sex couples, but most commonly used in reference to heterosexual couples who are emotionally and sexually intimate. Cohabitation has gained scholarly attention in recent time because it is now a culture in almost of Nigeria tertiary institutions, especially the government-owned Federal and State) institutions where the issue of on-campus accommodation is insufficient (Augustinah et al., 2018, p.28). This deviant living arrangements among youths has brought about resultant social problems to the society. Premarital sex, a preamble to cohabitation, has become an acceptable behaviour amongst many students in Nigeria tertiary institutions while abstinence has been jettisoned and no longer regarded as a virtue (Augustinah et al., 2018, P.28). Students, particularly, females are vulnerable to sexually transmitted disease such as gonorrhea, syphilis and HIV/AIDS. High rate of unwanted pregnancies leading to abortion in Nigeria tertiary institutions have been attributed to cohabitation, since most of these students are not ready for motherhood, they will do anything within their power to terminate such pregnancies when they occur (Adeniyi, 2019, p.12). Unrestrained and frequent sexually activities, especially among tertiary institutions students pose a serious threat to the institution of marriage/family and indicate lack of commitment to long-term relationships and courtship, a pointer to the erosion to Africa Cultural Values which places high premium on chastity before marriage and moral values (Augustinah et al., 2018, p.29). The widespread of cohabitation as alternative lifestyle and its increasing social acceptance among Nigeria tertiary institutions students has a far-reached implication on their individual wellbeing and academic performances (Adeniyi, 2019, p.11; Whitehand \& Popenoe, 2002).

@ECRTD-UK https://www.eajournals.org/ https://doi.org/10.37745/ijeld.2013 
International Journal of Education, Learning and Development

Vol. 10, No.1, pp.44-61, 2022

Print ISSN: 2054-6297(Print)

Online ISSN: 2054-6300 (Online)

Researchers on cohabitation among tertiary institutions students in Nigeria and other parts of the world have adduced some reasons to this social malaise. In Nigeria, inadequate of oncampus accommodation in almost all state-owned tertiary institutions has been identified as one of the major reasons for the widespread of the deviant behaviour among tertiary institutions students (Augustinah et al., 2018, p.29). High cost of off-campus type of accommodation (Goodwin, Mosher \& Chandra, 2010), love and affection (Prager, 2000; Arisukwu, 2013), pragmatic considerations to save money on rent and other living expenses (Manning \& Smock, 2005: Linday, 2000; Sasster, 2004; Arisukwu, 2013), exposure to foreign cultures and other sexual orientations through globalization (Fakeye, 2000), Higher tuition fees and other associated costs, need to study each other for marriage, financial distress, abandonment of valued African Culture, loss of Religious inclination, freedom from parental supervision and sexual gratification (Anna, 2020, p.140) have all been adduced as reasons why cohabitation is rampant in Nigeria tertiary institutions. Adeniyi (2019, pp.11-12) identified and explained types of cohabitation researchers have differentiated in their previous studies, as limited, premarital, substitute, No alternative and convenient cohabitation. This adduces to the fact that cohabitation is not a new phenomenon and has been first practiced by the older adults before the young adults took over the act (Augustinah, 2018, p.28). Cohabitation has a negative effects on the academic performance of tertiary Institutions students. In Sebia and Rees (2009) cited in Augustinah et al., (2018, p.30) revealed that there is relationship between students' Sexual relationship and their academic performance. They posited that when teenagers devoted greater energy and interest in sexual activity, their drive for academic performance will likely diminish unlike their peers who abstain from sex. The emotional trauma and depression which accompanied teenage sexual relationship when such relationship collapsed, ultimately affect academic performance. Academic performance of students cohabiting, particularly, the females usually suffers because of having to perform extra domestic chores such as cooking, washing, sexual activities etc for their partners. They find it difficult to graduate and make good grade because there is not enough time to read and prepare for examination (Adeniyi, 2019, p.13). Majority of these female students often withdraw from school, while some spend longer time than necessary as a result of carryovers (Anna, 2020, p.142). This is, aside, the fact that females student who gets pregnant and unable to cope will rigorous academic activities drop out of school because of unplanned motherhood at such tender age.

The Rufus Giwa Polytechnic, Owo, Ondo State, Nigeria as a state-owned polytechnic has shortage of on-campus accommodation for its teeming students and this is peculiar to almost all the state owned tertiary institutions in Nigeria. This has forced making most students to resort to renting off-campus residential buildings. The desire for intimacy and sex on regular basis, and, other unwholesome acts with reckless impunity have been one of the major reasons why cohabitation is rampant in the institution. It has been found out that most of these cohabiters have their own separate accommodation but choose to live a "couple's life" and

@ECRTD-UK https://www.eajournals.org/ https://doi.org/10.37745/ijeld.2013 
sometimes return to their apartment when they get a notice of visitation from their parents and siblings.

\section{Statement of the Problem}

Cohabitation, a situation where two unmarried people who are emotionally, romantically and sexually intimate choose to live together as couple has gained notoriety among adults and youths, including tertiary institutions students in many countries of the world. This alternative lifestyle with its resultant social problems in Nigeria tertiary institutions has become a subject of concern to researchers, parents and other important stakeholders in Nigeria educational sector. This phenomenon is worrisome because of its attendants social crisis such as, normalization of pre-marital sex among tertiary institutions students, spread of sexually transmitted diseases such as gonorrhea, syphilis and HIV/AIDS, prevalence of unwanted teenage pregnancy, increase rate of abortions which diminished students' drive for academic performance (Augustinah et al., 2018, p.31).

The main goal of a student who acquires tertiary education is to obtain a certificate which will qualify him/her to secure a good employment opportunities and better his/her lives. However, cohabitation, aside from the sexual behavior arising from pre-marital sex, has a far-reached implication on individual (cohabiters) wellbeing and academic performance which is a prelude for acquiring tertiary education certificate. The study thus, investigates the reasons for cohabitation among tertiary institutions students, the effects of cohabitation on academic performance of students and possible solutions to the menace. The scope of the study is limited to Rufus Giwa Polytechnic, Owo, Ondo State, Nigeria. It is a state-owned polytechnic and the first tertiary institution in Ondo State, Nigeria. Like almost other state-owned tertiary institutions across the country, the polytechnic is faced with inadequate hostel accommodation for its students. A problem which ultimately accounts for one of the reasons cohabitation is rampant among the students of the institution.

\section{Research Questions}

1. What are the causes of cohabitation among students in Rufus Giwa Polytechnic, Owo, Ondo State, Nigeria?

2. What are the consequences of cohabitation on academic performance of Rufus Giwa Polytechnic Owo, Ondo State, Nigeria?

3. What are the possible solutions to cohabitation among students in Rufus Giwa Polytechnic Owo, Ondo State, Nigeria?

\section{Formulation of Hypotheses}

$\mathbf{H}_{\mathbf{o}}$ - There is no significant difference between male and female students' responses on the effects of cohabitation on academic performance.

@ECRTD-UK https://www.eajournals.org/

https://doi.org/10.37745/ijeld.2013 
H1- There is significant difference between male and female students' responses on the effects of cohabitation on academic.

\section{METHODOLOGY}

The technique used for this study was a descriptive survey method. The study population comprises of both National Diploma (ND) and Higher National Diploma (HND) students of Rufus Giwa Polytechnic Owo, Ondo State, Nigeria. The investigator used purposive sampling method to select a total number of 360 students, randomly sampled from the six faculties in the polytechnic, namely; Agricultural Technology, Applied Sciences, Business Studies, Engineering Technology, Environmental Studies and Social Sciences \& Communication Studies. The instrument used by the investigator to collect data from the respondents is known as "The Effects of Male and Female Cohabitation On Academic Performance Of Nigeria Tertiary Institutions Students Questionnaire". The instrument was divided into two major sections. Section A comprised of demographic data of the respondents while section B consisted of 20 items questionnaire that sought to elicit information on the effects of male and female cohabitation on academic performance of Nigeria tertiary institutions students using Likert-style rating on 5-point scale e.g Strongly Agreed $(\mathrm{SA})=4$, Agreed $(\mathrm{A})=3$, Disagreed $(D)=2$ and Strongly Disagreed $(S D)=1$. The instrument used for the study were reviewed and adjudged adequate and valid by experts in gender studies. The investigator retrieved 341 out of the 360 questionnaires distributed to respondents on the subject matter. The investigator got the data collected from the fieldwork, scored, collated and used both descriptive and inferential statistic like chi-square, frequency counts, and percentage to analyze the data collected. The study provided answers to the three research questions raised for the study.

\section{CONCEPTUAL DEFINITION}

\section{Cohabitation}

Cohabitation refers to when two people who are romantically involved choose to live together without making the formal commitment of marriage. Cohabitating couples are typically emotional and sexually intimate (Adeniyi, 2019, p.10). It is not just loosely used to refer to people who are merely sharing a living space or who call themselves roommates, but who are sexually intimate. It is both a status and a process; also an alternative type of housing for at least of the cohabiters (Abdullahi, 2013). Cohabitation can be encapsulated to either heterosexual or same sex couples but mostly used in reference to heterosexual couples who are emotionally and sexually intimate (Augustinah, 2018, p.28). It is a new form of living

@ECRTD-UK https://www.eajournals.org/ https://doi.org/10.37745/ijeld.2013 
arrangements in a situation of flux associated with changing lifestyle, societal value and norm (Pollard, 2008).

\section{Tertiary Institution}

Tertiary institutions are the third level or post secondary education (Bania \& Kvernmo, 2016). Tertiary institutions measure academic success in term of GPA (Honicke \& Broadbent, 2010), grades (Glass \&West-month, 2014), percentage (Bailey \& Philips, 2016), retention in course (Kruzkevic et al., 2012), degree completion within time (Gesevic et al., 2016) and by using academic success scales (Ainin, Naqshbandi, Moghavvemi, \& Jaafar, 2015). Tertiary institutions in Nigeria are categorized into University, Polytechnic, Monotechnic and College of Education which can be federal, state or private. Universities award Bsc degree to students after a minimum of four (4) years course while polytechnic and monotechnic are known to be practically inclined and skillful and they awarded National Diploma (ND)/ Higher National Diploma (HND) certificates. Colleges of Education train teachers and award Nigeria Certificate in Education (NCE).

\section{THEORETICAL FRAMEWORK：RATIONAL CHOICE THEORY}

The Rational choice theory was propounded by Adam Smith, who is considered the originator of the theory in his essay "An inquiry into the Nature and causes of the wealth of Nations" in 1776. He proposed human nature's tendency toward self-interest resulted in prosperity. The rational choice theory, also known as choice theory or rational action theory explains social phenomenon as outcomes of individual choices that can in some way be construed as rational. Choices are ' rational' If they meet some consistency criterion as defined by a decision theory and are suitable to achieve specific goals, given the constraints of situation.

According to Abell (2000) rational choice theory is understanding individual actors as acting or more likely interacting in a manners such that they can be deemed to be doing the best they can for themselves, given their objectives. By making calculative decisions, it is considered as rational action, individual are often making calculative decisions in social situation by weighing out the pros and cons of an action taken towards a person. Rational choice theory has been used by social scientist to understand human behavior. The rational choice theory is based on assumption that individuals choose a course of action that is most in line with their personal preferences. Abell (2000) cited in Micheal (2013, p.23) noted few assumptions made by Rational Choice Theorists which includes:

@ECRTD-UK https://www.eajournals.org/ https://doi.org/10.37745/ijeld.2013 


\section{* Individualism}

It is individual who ultimately take actions in the society. Individuals, as actors, behave and act always as rational being, self-conscious, self-calculating and self-maximizing, these individual social actions are the ultimate source of larger social outcomes.

\section{* Optimality}

Individual choose their actions optimally, given their individual preferences as well as the opportunities or constraint as taking place individual faces. Abell, (2000) defines optimality as taking place when no other course of social action would be preferred by the individual over the course of the action the individual was chosen.

\section{* Structures}

Structures and norms dictate a single course of action is merely special cases Of Rational Choice Theory. In other words, the range of choices in other circumstances differs from choices in a strong structural circumstance, where there may be only one choice.

\section{* Self-regarding interest}

This assumption states that the action of the individual are concerned entirely with his or her own welfare.

\section{* Rationality}

This appears the most predominant assumption of the rational choice theory. All individual according to the assumption act in way that would benefit them more, every individual is more like to undertake courses of actions that they perceive to be the best possible option and one that would immensely be to their own advantage.

Applied to the purpose of the study, it is to be observed that individual student cohabiting takes a rational decision to do as a result of prevailing shortages of residential accommodation in almost all government owned tertiary institution in Nigeria, coupled with the high cost of offcampus residential accommodation. Since very individual is more likely to undertake actions that they perceive to be best option and one that would immensely be to their own advantage, the need to save money from Higher tuition fees and other associated costs; sexual gratification (Anna, 2020, p.141); emotional support for each other (Augustinah et al., 2018, p.29); test of compatibility (Elise, 2004); high cost of housing and harsh economic realities (Goodwin et al., 2010); motivation to live together for love or at least due to affection and attraction (Prager, 2000) have all informed reasons why students choose to cohabite together in Nigeria tertiary institutions. However, some of the reasons adduced for engaging in this social malaise have resultant effects on academic performance of students in tertiary institutions. 
International Journal of Education, Learning and Development

Vol. 10, No.1, pp.44-61, 2022

Print ISSN: 2054-6297(Print)

Online ISSN: 2054-6300 (Online)

\section{FINDINGS}

Table 1: Frequency Distribution on Percentage of Characteristics of Respondents

\begin{tabular}{|l|l|l|l|}
\hline S/N & Characteristic & Frequency & Percentage (\%) \\
\hline 1 & Gender & & \\
& Male & 149 & 43.7 \\
& Female & 192 & 56.3 \\
& Total & $\mathbf{3 4 1}$ & $\mathbf{1 0 0 . 0}$ \\
\hline 2. & Age & & \\
& $15-20$ & 96 & 28.2 \\
& $21-26$ & 164 & 48.1 \\
& $27-32$ & 74 & 21.6 \\
& 33-38 & 7 & 2.1 \\
& Total & $\mathbf{3 4 1}$ & $\mathbf{1 0 0 . 0}$ \\
\hline 3. & Faculty & & \\
& Applied sciences & 86 & 25.2 \\
& Agricultural Technology & 40 & 11.7 \\
& Business Studies & 75 & 22.0 \\
& Engineering Technology & 40 & 11.7 \\
& Environmental Studies & 49 & 14.4 \\
& Social Sciences \& Communication Studies & 51 & 15.0 \\
& Total & $\mathbf{3 4 1}$ & $\mathbf{1 0 0 . 0}$ \\
\hline 4. & Level & & \\
& ND 1 & 74 & 21.7 \\
& ND II & 114 & 33.4 \\
& HND I & 87 & 25.5 \\
& HND II & 66 & 19.4 \\
& Total & $\mathbf{3 4 1}$ & $\mathbf{1 0 0 . 0}$ \\
\hline 5. & Type of Accommodation & & \\
& On campus accommodation & 139 & 40.8 \\
& Off campus accommodation & 202 & 59.2 \\
& Total & $\mathbf{3 4 1}$ & $\mathbf{1 0 0 . 0}$ \\
\hline
\end{tabular}

The Table shows that majority (56.3\%) of the respondents are females while $43.7 \%$ of the respondents are between age 15-20 years while only $2.1 \%$ are between 33-38years. The Faculty of Applied Sciences accounts for $25.2 \%$ of the respondents more than other faculties, while both Faculty of Agricultural Technology and Engineering Technology are 11.7\%. National Diploma (I \& II) Level accounts for 55.1\% while 59.2\% of the respondents live outside the institution. Based on the majority, it was summed that most students of the institution live in off campus accommodation. 


\section{Research Question 1: what are the causes of Cohabitation among Students in Rufus Giwa Polytechnic, Owo, Ondo State, Nigeria.}

Table 2: Frequency Distribution on Percentage on causes of Students Cohabitation.

\begin{tabular}{|c|c|c|c|c|}
\hline $\mathbf{S} / \mathbf{N}$ & Causes of cohabitation among Students & Response & Frequency & $\begin{array}{l}\text { Percentage } \\
(\%)\end{array}$ \\
\hline 1 & $\begin{array}{l}\text { Some students cohabit because of high tuition fees } \\
\text { Total }\end{array}$ & $\begin{array}{l}\text { Strongly Agreed } \\
\text { Agreed } \\
\text { Disagreed } \\
\text { Strongly Disagreed }\end{array}$ & $\begin{array}{r}70 \\
80 \\
122 \\
69 \\
\mathbf{3 4 1}\end{array}$ & $\begin{array}{l}20.5 \\
23.5 \\
35.8 \\
20.2 \\
\mathbf{1 0 0 . 0}\end{array}$ \\
\hline 2. & $\begin{array}{l}\text { Shortage of hostel accommodation within the school } \\
\text { could make some students stay off campus and } \\
\text { indulge in cohabitation. } \\
\text { Total }\end{array}$ & $\begin{array}{l}\text { Strongly Agreed } \\
\text { Agreed } \\
\text { Disagreed } \\
\text { Strongly Disagreed }\end{array}$ & $\begin{array}{r}119 \\
95 \\
70 \\
57 \\
\mathbf{3 4 1}\end{array}$ & $\begin{array}{l}34.9 \\
27.9 \\
20.5 \\
16.7 \\
\mathbf{1 0 0 . 0}\end{array}$ \\
\hline 3. & $\begin{array}{l}\text { Some students cohabit due to high rent of } \\
\text { accommodation outside the institution. } \\
\text { Total }\end{array}$ & $\begin{array}{l}\text { Strongly Agreed } \\
\text { Agreed } \\
\text { Disagreed } \\
\text { Strongly Disagreed }\end{array}$ & $\begin{array}{r}159 \\
87 \\
63 \\
32 \\
\mathbf{3 4 1}\end{array}$ & $\begin{array}{c}46.6 \\
25.5 \\
18.5 \\
9.4 \\
\mathbf{1 0 0 . 0}\end{array}$ \\
\hline 4. & $\begin{array}{l}\text { Due to financial difficulties, some students cohabit to } \\
\text { save cost. } \\
\text { Total }\end{array}$ & $\begin{array}{l}\text { Strongly Agreed } \\
\text { Agreed } \\
\text { Disagreed } \\
\text { Strongly Disagreed }\end{array}$ & $\begin{array}{r}140 \\
90 \\
61 \\
50 \\
\mathbf{3 4 1}\end{array}$ & $\begin{array}{l}41.1 \\
26.4 \\
17.9 \\
14.7 \\
\mathbf{1 0 0 . 0}\end{array}$ \\
\hline 5. & $\begin{array}{l}\text { Some students may take to cohabitation for sexual } \\
\text { gratification. } \\
\text { Total }\end{array}$ & $\begin{array}{l}\text { Strongly Agreed } \\
\text { Agreed } \\
\text { Disagreed } \\
\text { Strongly Disagreed }\end{array}$ & $\begin{array}{r}152 \\
95 \\
62 \\
32 \\
341\end{array}$ & $\begin{array}{c}44.6 \\
27.9 \\
18.2 \\
9.4 \\
\mathbf{1 0 0 . 0}\end{array}$ \\
\hline 6. & $\begin{array}{l}\text { Some students live a couple's life because they do not } \\
\text { want to lose their boyfriends/girlfriends. } \\
\text { Total }\end{array}$ & $\begin{array}{l}\text { Strongly Agreed } \\
\text { Agreed } \\
\text { Disagreed } \\
\text { Strongly Disagreed }\end{array}$ & $\begin{array}{c}124 \\
141 \\
50 \\
26 \\
\mathbf{3 4 1}\end{array}$ & $\begin{array}{c}36.4 \\
41.3 \\
14.7 \\
7.6 \\
\mathbf{1 0 0 . 0}\end{array}$ \\
\hline 7. & $\begin{array}{l}\text { Some students cohabit outside the school because } \\
\text { they cannot abide with the hostel rules and regulations } \\
\text { in the institution. } \\
\text { Total }\end{array}$ & $\begin{array}{l}\text { Strongly Agreed } \\
\text { Agreed } \\
\text { Disagreed } \\
\text { Strongly Disagreed }\end{array}$ & $\begin{array}{r}166 \\
86 \\
56 \\
33 \\
\mathbf{3 4 1}\end{array}$ & $\begin{array}{c}48.7 \\
25.2 \\
16.4 \\
9.7 \\
\mathbf{1 0 0 . 0}\end{array}$ \\
\hline 8. & $\begin{array}{l}\text { Cohabitation among some students may be due to } \\
\text { their freedom from parental control and supervision. } \\
\text { Total }\end{array}$ & $\begin{array}{l}\text { Strongly Agreed } \\
\text { Agreed } \\
\text { Disagreed } \\
\text { Strongly Disagreed }\end{array}$ & $\begin{array}{r}154 \\
133 \\
41 \\
13 \\
\mathbf{3 4 1} \\
\end{array}$ & $\begin{array}{c}45.2 \\
39.0 \\
12.0 \\
3.8 \\
\mathbf{1 0 0 . 0}\end{array}$ \\
\hline
\end{tabular}


The Table shows that respondents agreed to almost all the items on Table 2 except item 1 which says that one of the reasons why students cohabit in Rufus Giwa Polytechnic is because of high tuition fees. Respondents disagreed with the item with percentage of $56.0 \%$. The researcher found out that $62.8 \%$ of the respondents agreed that shortage of accommodation within the school make some students to resort to cohabitation, $72.1 \%$ of the respondents indicated high rent of accommodation outside the institution, while $67.5 \%$ ascribed financial difficulties as one of the causes of cohabitation among students. A total of $72.5 \%$ adduce sexual gratification as reason why students cohabit, and $77.7 \%$ said they cohabit because they don't want to lose their partners. $73.9 \%$ of the respondents agreed that students cohabit outside the school because they cannot abide with the institution's Hostel rules and regulations, while $84.2 \%$ ascribed cohabitation to freedom from parental control and supervision.

\section{Research Question 2: What are the effects of Cohabitation on academic performance of Students in Rufus Giwa Polytechnic, Owo, Ondo State, Nigeria.}

Table 3: Frequency Distribution on Percentage on effects of Cohabitation on academic performance of Students.

\begin{tabular}{|c|c|c|c|c|}
\hline $\mathbf{S} / \mathbf{N}$ & $\begin{array}{l}\text { Effects of cohabitation on academic } \\
\text { performance of students }\end{array}$ & Response & Frequency & $\begin{array}{l}\text { Percentage } \\
(\%)\end{array}$ \\
\hline 1. & $\begin{array}{l}\text { Students cohabiting sometimes do extra } \\
\text { domestic chores such as washing clothes, } \\
\text { cooking etc that may affect academic studies. } \\
\text { Total }\end{array}$ & $\begin{array}{l}\text { Strongly Agreed } \\
\text { Agreed } \\
\text { Disagreed } \\
\text { Strongly Disagreed }\end{array}$ & $\begin{array}{r}129 \\
118 \\
60 \\
34 \\
\\
\mathbf{3 4 1}\end{array}$ & $\begin{array}{l}37.8 \\
34.6 \\
17.6 \\
10.0 \\
\mathbf{1 0 0 . 0}\end{array}$ \\
\hline 2. & $\begin{array}{l}\text { Sometimes in cohabitation, sex is used as } \\
\text { object of abuse and the psychological trauma } \\
\text { could affect academic studies of cohabiters } \\
\text { especially the females. } \\
\text { Total }\end{array}$ & $\begin{array}{l}\text { Strongly Agreed } \\
\text { Agreed } \\
\text { Disagreed } \\
\text { Strongly Disagreed }\end{array}$ & $\begin{array}{r}192 \\
94 \\
52 \\
3 \\
341 \\
\end{array}$ & $\begin{array}{c}56.3 \\
27.6 \\
15.2 \\
0.9 \\
\mathbf{1 0 0 . 0}\end{array}$ \\
\hline 3. & $\begin{array}{l}\text { Frequent and unrestrained sexual activities } \\
\text { could affect the health of cohabiting students } \\
\text { and this could affect their academic } \\
\text { performance. } \\
\text { Total }\end{array}$ & $\begin{array}{l}\text { Strongly Agreed } \\
\text { Agreed } \\
\text { Disagreed } \\
\text { Strongly Disagreed }\end{array}$ & $\begin{array}{r}156 \\
138 \\
26 \\
21 \\
\\
\mathbf{3 4 1}\end{array}$ & $\begin{array}{r}45.7 \\
40.5 \\
7.6 \\
6.2 \\
\\
\mathbf{1 0 0 . 0}\end{array}$ \\
\hline
\end{tabular}


Online ISSN: 2054-6300 (Online)

\begin{tabular}{|c|c|c|c|c|}
\hline 4. & $\begin{array}{l}\text { Cohabiting students often spend their money } \\
\text { to provide for their cohabiting partners' } \\
\text { needs and may lack money to buy handouts, } \\
\text { stationeries, lab coat etc which ultimately } \\
\text { may affect their studies. } \\
\text { Total }\end{array}$ & $\begin{array}{l}\text { Strongly Agreed } \\
\text { Agreed } \\
\text { Disagreed } \\
\text { Strongly Disagreed }\end{array}$ & $\begin{array}{r}142 \\
114 \\
65 \\
20\end{array}$ & $\begin{array}{r}41.6 \\
33.4 \\
19.1 \\
5.9\end{array}$ \\
\hline 5. & $\begin{array}{l}\text { Cohabitation increases risk of unwanted } \\
\text { Pregnancies among cohabiting girls and this } \\
\text { may affect their academic performance. } \\
\text { Total }\end{array}$ & $\begin{array}{l}\text { Strongly Agreed } \\
\text { Agreed } \\
\text { Disagreed } \\
\text { Strongly Disagreed }\end{array}$ & $\begin{array}{r}176 \\
139 \\
26 \\
0 \\
\\
\mathbf{3 4 1}\end{array}$ & $\begin{array}{r}51.6 \\
40.8 \\
7.6 \\
0 \\
\\
\mathbf{1 0 0 . 0}\end{array}$ \\
\hline 1. & $\begin{array}{l}\text { Most cohabiting students sometimes miss } \\
\text { lecture classes because of little or no time to } \\
\text { adequately prepare and this could affect their } \\
\text { academic studies. } \\
\text { Total }\end{array}$ & $\begin{array}{l}\text { Strongly Agreed } \\
\text { Agreed } \\
\text { Disagreed } \\
\text { Strongly Disagreed }\end{array}$ & $\begin{array}{r}116 \\
142 \\
72 \\
11 \\
\mathbf{3 4 1}\end{array}$ & $\begin{array}{r}34.0 \\
41.6 \\
21.1 \\
3.3 \\
\mathbf{1 0 0 . 0}\end{array}$ \\
\hline 2. & $\begin{array}{l}\text { Most students cohabiting may find it difficult } \\
\text { to make good grades because of insufficient } \\
\text { time to read. } \\
\text { Total }\end{array}$ & $\begin{array}{l}\text { Strongly Agreed } \\
\text { Agreed } \\
\text { Disagreed } \\
\text { Strongly Disagreed }\end{array}$ & $\begin{array}{r}112 \\
135 \\
61 \\
33 \\
\\
\mathbf{3 4 1} \\
\end{array}$ & $\begin{array}{r}32.8 \\
39.6 \\
17.9 \\
9.7 \\
\\
\mathbf{1 0 0 . 0}\end{array}$ \\
\hline 3. & $\begin{array}{l}\text { Cohabitation may brings unwanted } \\
\text { pregnancies that could result into abortion } \\
\text { which ultimately may affect academic } \\
\text { performance of cohabiting students } \\
\text { especially females. } \\
\text { Total }\end{array}$ & $\begin{array}{l}\text { Strongly Agreed } \\
\text { Agreed } \\
\text { Disagreed } \\
\text { Strongly Disagreed }\end{array}$ & $\begin{array}{r}94 \\
102 \\
60 \\
85 \\
\\
\\
\mathbf{3 4 1} \\
\end{array}$ & $\begin{array}{l}27.6 \\
29.9 \\
17.6 \\
24.9 \\
\\
100.0\end{array}$ \\
\hline
\end{tabular}

The Table shows that $72.4 \%$, which represents majority agreed that an extra domestic chore has impact on students' academic performance. $83.9 \%$ of the sampled participants affirmed that psychological trauma arising from sexual abuse by cohabiting students could affect their academic performance, while $86.2 \%$ agreed that frequent sexual activities could affect academic performance of cohabiting students. Majority of the respondents (75.0\%) agreed that cohabiting students spend most of their money on their partners with little or no money to buy necessary materials that could aid their academic performance. $92.4 \%$ of the sampled participants agreed that cohabitation increase risk of unwanted pregnancies that could affect students concentration on their studies while $75.6 \%$ believed that cohabiting students often 
miss lecture classes due to inadequate time to prepare. Also most of the respondents $(72.4 \%)$ agreed that cohabitation contributes to students making poor grades in school. Finally, 57.5\% of the respondents agreed that cohabitation increases unwanted pregnancies that may result into abortion which ultimately may affect academic performance among girls. These therefore, highlighted and confirmed that cohabitation affect student's academic performance negatively.

Research Question 3: Distribution on Percentage on possible solutions to Cohabitation among Students in Rufus Giwa Polytechnic, Owo, Ondo State, Nigeria.

\begin{tabular}{|c|c|c|c|c|}
\hline $\mathbf{S} / \mathbf{N}$ & $\begin{array}{l}\text { Possible solutions to cohabitation among } \\
\text { students in Rufus Giwa Polytechnic, Owo, Ondo } \\
\text { State, Nigeria. }\end{array}$ & Response & Frequency & $\begin{array}{l}\text { Percentage } \\
(\%)\end{array}$ \\
\hline 1. & $\begin{array}{l}\text { The management of the institution should provide } \\
\text { more hostel accommodation for students. } \\
\text { Total }\end{array}$ & $\begin{array}{l}\text { Strongly Agreed } \\
\text { Agreed } \\
\text { Disagreed } \\
\text { Strongly Disagreed }\end{array}$ & $\begin{array}{r}192 \\
94 \\
52 \\
3 \\
\\
\mathbf{3 4 1}\end{array}$ & $\begin{array}{r}56.3 \\
27.6 \\
15.2 \\
0.9 \\
\\
\mathbf{1 0 0 . 0}\end{array}$ \\
\hline 2. & $\begin{array}{l}\text { The house rent charge students living off campus } \\
\text { accommodation should be moderate and } \\
\text { affordable. } \\
\text { Total }\end{array}$ & $\begin{array}{l}\text { Strongly Agreed } \\
\text { Agreed } \\
\text { Disagreed } \\
\text { Strongly Disagreed }\end{array}$ & $\begin{array}{r}94 \\
102 \\
60 \\
85 \\
\mathbf{3 4 1}\end{array}$ & $\begin{array}{l}27.6 \\
29.9 \\
17.6 \\
24.9 \\
\\
\mathbf{1 0 0 . 0}\end{array}$ \\
\hline 3. & $\begin{array}{l}\text { Parents should often check on their wards in school } \\
\text { to know how they are faring and living. } \\
\text { Total }\end{array}$ & $\begin{array}{l}\text { Strongly Agreed } \\
\text { Agreed } \\
\text { Disagreed } \\
\text { Strongly Disagreed }\end{array}$ & $\begin{array}{r}129 \\
118 \\
60 \\
34 \\
\mathbf{3 4 1}\end{array}$ & $\begin{array}{l}37.8 \\
34.6 \\
17.6 \\
10.0 \\
\\
\mathbf{1 0 0 . 0}\end{array}$ \\
\hline 4. & $\begin{array}{l}\text { Parents should teach their children moral education } \\
\text { and God's words on the danger of pre-marital sex } \\
\text { and cohabitation. } \\
\text { Total }\end{array}$ & $\begin{array}{l}\text { Strongly Agreed } \\
\text { Agreed } \\
\text { Disagreed } \\
\text { Strongly Disagreed }\end{array}$ & $\begin{array}{r}116 \\
142 \\
72 \\
11 \\
\mathbf{3 4 1} \\
\end{array}$ & $\begin{array}{c}34.0 \\
41.6 \\
21.1 \\
3.3 \\
\mathbf{1 0 0 . 0}\end{array}$ \\
\hline
\end{tabular}

From the Table above, it was indicated that majority of the sampled participants $(83.9 \%)$ suggested that management should build more hostel accommodation as a means of combating cohabitation among students. 57.5\% advised that house rent charge students living off campus accommodation be moderate and affordable. Also, $72.4 \%$ of the respondents said parents should often check on their wards in school as a means of knowing how they are faring and living, while $75.6 \%$ suggested that parents should teach their children moral education and God's words on danger of pre-marital sex and cohabitation. 
International Journal of Education, Learning and Development

Vol. 10, No.1, pp.44-61, 2022

Print ISSN: 2054-6297(Print)

Online ISSN: 2054-6300 (Online)

Table 5: Independent Sample T-test for Gender response on effects of cohabitation on academic performance of students.

\begin{tabular}{|l|l|l|l|l|}
\hline Levene's Test for Equality of Variance & & & & \\
\hline F & P-value & t & df & p-value \\
1.074 & 0.301 & 0.845 & 339 & 0.399 \\
\hline
\end{tabular}

Decision rule: If P-value is less than significant level of 0.05 , reject the Null hypotheses, which means there is no significant different between male and female students responses on the effects of cohabitation on academic performance.

\section{DISCUSSION}

One of the findings of the study is that some students cohabit due to shortage of hostel accommodation within the institution with $72.8 \%$. This finding agrees with Svodziwa and Kurete (2017) where they explained that inadequate of accommodation within the school, makes students to resort to living off-campus residential accommodation, and thus, they cohabit. The study found out in Table 2 that due to financial difficulties and high rate of offcampus accommodation some students cohabit to save cost. This finding supports assertion of Adeniyi (2019) who argued that students in tertiary institutions cohabit as a way to save on rent, food and other living expenses. The study found out that one of the reasons why students cohabit is not because of high tuition fees with $56.0 \%$ of the respondents disagreed on the statement. This finding contradicts Anna (2020) who opined that one of the causes of students cohabitation is due to high tuition fees. The study also revealed that students in tertiary institutions may take to cohabitation for sexual gratification with $72.5 \%$. This finding gives credences to Alo and Akinde (2010) who pointed out that some of the consequences are unprotected sex and its attendant effects such as unwanted pregnancies and other sexually transmitted diseases (STD). The study found out that cohabitation increases risk of unwanted pregnancies among cohabiting girls with $92.4 \%$ in Table 3 . The finding aligns with Adeniyi (2019) who posited that high rate of abortion in tertiary institutions can be attributed to cohabitation. He opined that some of the cohabiting female students often get pregnant and because they are not prepared for motherhood at such tender age, some of them take to abortion to get rid of the pregnant that could pose a serious health risk to them. The result in table 5 revealed that there is no significant difference between male and female students' responses on the effects of cohabitation on academic performance. The finding has clearly shown that gender of student cohabiting does not matters on their assessment of effects of cohabitation on academic performance. They have all assessed the effects of cohabitation on academic performance of students in the same way.

@ECRTD-UK https://www.eajournals.org/ https://doi.org/10.37745/ijeld.2013 


\section{CONCLUSION}

Cohabitation is common among students of Rufus Giwa Polytechnic, Owo, Ondo State, Nigeria as revealed by the findings of the study. Some of the causes attributed to cohabitation are shortage of on-campus accommodation, high rent of off-campus residential accommodation, financial difficulties, sexual gratification among others. The study shows that cohabitation can lead to cases of unwanted pregnancy, abortion, psychological trauma, lack of concentration etc that could affect academic performance of students engaging in such act. Therefore, the act is shameful and must be discouraged.

\section{RECOMMENDATIONS}

As a result of the findings and the conclusion reached by the researcher, the following recommendations are suggested as possible solutions to the menace of cohabitation in Rufus Giwa Polytechnic, Owo, Ondo State, Nigeria.

1.That coordinated efforts should be made by Management of Rufus Giwa Polytechnic, Owo, Ondo State, Nigeria to put up adequate number of Halls of residence for students.

2.The Polytechnic authority should relaxes its policy of immediate payment of school fees as pre-requisite for allocation of halls of residence to students so that many students can live in the school.

3. Students' handbook should be reviewed to accommodate what constitutes cohabitation and its consequences on students indulging in such an act.

4.Parents and guardians should always pay frequent and unscheduled visits to their children/wards in tertiary institution so as to know how they are faring and living.

5.Concerted efforts should be made by Management of the institution by liaising with landlord association outside the Polytechnic on how to make off-campus residential accommodations affordable to students.

6.Regular sensitization programmes should be done for students on the danger of pre-marital sex and cohabitation.

\section{REFERENCES}

Abdullahi, M. (2013). Consequence of pre-marital sex among the youth, a study of University of Maiduguri. Journal of Humanities and Social Science of University 10(1), 10-17. https://doi.org/10.9790/0837-01011017.

@ECRTD-UK https://www.eajournals.org/

https://doi.org/10.37745/ijeld.2013 
International Journal of Education, Learning and Development

Vol. 10, No.1, pp.44-61, 2022

Print ISSN: 2054-6297(Print)

Online ISSN: 2054-6300 (Online)

Adeniyi, A.O. (2019). The Effects of Cohabitation on Academic Performance of Students in Tertiary Institutions in Nigeria. International Journal of Sociology and Anthropology Research, Vol.5 (2), PP.10-15.

Ainin, S., Naqshbandi, M.M., Moghavvemi, S., \& Jaafar, N.I (2015). Facebook usage, Socialization and academic performance. Computers \& Education, 83, 64-73.

Alo, O.A \& Akinde, I.S (2010). Premarital sexual activities in an Urban society of southwest, Nigeria. http://www.ea-formal.com.

Anna, O. (2020). Cohabitation Among University students in Oyo State, South West Nigeria; causes and consequences: Implications for counseling. Journal of Education and Learning, Vol. 9(2) pp.140-147.

Arisukwu, C.O. (2014). Cohabitation Among University of Ibadan Undergraduates Students. Research on Humanities and Social Sciences; vol.3, No.5.

Augustinah, N.D, Bola Margaret, T.A \& Louis Omolayo, A.L. (2013). Cohabitation in Nigeria Tertiary Institutions: A case study of Adekunle Ajasin University, Akungba-Akoko, Ondo State, Nigeria. International Journal of Social scienes and Humanities, Vol. 3(1), pp.27-37.

Balley, T.H., \& Philips, L.J. (2016). The influence of motivation and adaptation on students subjective well-being, meaning in life and academic performance. Higher Education Research \& Development, 35(2), 201-216.

Bania, E.V., \& Kvernmo, S.E (2016). Tertiary education and its association with mental health indicators and educational factors among Arctic young adults: The NAAHS Cohort study. International, Journal of Circumpolar Health, 75(1). doi:10.3402/ijch.v75.32085.

Elise, K. (2004). “Cohabitation: Just a phase? Psychology Today 37:28.

Fakeye, D.O (2000). Globalization and Cultural Erosion: Impact on Sexuality in Nigeria. http://www.cscanada.net

Gasevic, D., Dawson, S., Rogers, T., \& Gasevic, D. (2016). Learning analytics should not promote one size fits all: The effects of instructional Conditions in predicting academic success. The Interest and Higher Education, 28, 68-84.

Glass, C.R, \& Westmont, C.M. (2014). Comparative effects of belongingness on the academic success and cross-cultured interactions of domestic and international students. International Journal of Intercultural Relations, 38, 106-119.

Goodwin, P.y., Mosher, W.D., Chandra, A. (2010). "Marriage and cohabitation in the United States: A statistical portrait based on cycle 6 (2002) of the National Survey of Family Growth (National Centre for Health Statistics): Vital Health Statistics 23:1-55.

@ECRTD-UK https://www.eajournals.org/

https://doi.org/10.37745/ijeld.2013 
International Journal of Education, Learning and Development

Vol. 10, No.1, pp.44-61, 2022

Print ISSN: 2054-6297(Print)

Online ISSN: 2054-6300 (Online)

Honicke, T., \& Broadbent, J. (2016). The influence of academic self-efficacy on academic performance: A systematic review. Education Research Review, 17, 63-84.

Kruzicerk, S.M., Barisic, K.J., Banozic, A., Estesan, C.D., Sapunar, D., \& Puljak, L. (2012). Predictors of attrition and academic success of medical students: A30-years retrospective study. Plos One, 7(6). doi:10.1371/journal.pone.0039144.

Manning, W., Cohen, J., \& Smock, P. (2011). “ The Role of Romantic partners, family and peer Networks in Dating couples' views about cohabitation". Journal of Adolescent Research. 26(1):115-149.

Maryum, F., \& Saima, M.A. (2017). Tertiary Academic Success: A Review of Factors in the Context of Ecological Model. Journal of Education \& Social Sciences Vol. 5(2): 87105, Doi:10.20547/jess0521705201.

Micheal, I.O. (2013). Rational Choice Theory: Assumptions, Strengths, and Greatest Weaknesses in Application Outside the Western Milieu context. Arabian Journal of Business and Management Review (Nigerian chapter) vol.1, No3, pp.90-99.

Pollard, T. (2008). Cohabitation-A Deadly Trends in Tertiary Institutions at Bursting point: A case study of the University of Ibadan; Ibadan IFRA.

Prager, D. (2000). Judaism Sexual Revolution: Why Judaism (and then Christianity) rejected Homosexuality" Orthodoxy Today. www.catholiceducation.org/en/marriage-andfamily/sexuality/judaism-s-sexual-revolution-why-judaism-reject-homosexuality.htm/

Sabia, J.J., \& Rees, D.I. (2009). The effects of sexual abstinence on females' educational attainment. Demography, 46(4), 695-715.

Sovodziwa, G; \& Kurete, T.(2017). The psychological consequences of cohabitation among students in Tai Solarin University of Education, Ijagun, Ogun State, Nigeria. O'zean. Journal of Applied Science, 6(2), 65-70.

Whitehead, B \& Popenoe, D. (2006). The State of our unions, the social health of marriage in America. Piscatoway NJ: National Marriage Project.

@ECRTD-UK https://www.eajournals.org/

https://doi.org/10.37745/ijeld.2013 
International Journal of Education, Learning and Development

Vol. 10, No.1, pp.44-61, 2022

Print ISSN: 2054-6297(Print)

Online ISSN: 2054-6300 (Online)

Saka-Olokungboye, Nurudeen was born on $2^{\text {nd }}$ July, 1976 in Ikare-Akoko, Akoko North East Local Government Area, Ondo State, Nigeria. He holds a Bachelor of Science (B.sc) degree in Sociology from the Adekunle Ajasin University, Akungba Akoko, Ondo State, Nigeria. He is happily married and has three beautiful daughters. He is an academic in Rufus Giwa Polytechnic, Owo, Ondo State, Nigeria where he has been working for the past ten years teaching students and conducting research on social problems. He has 10 published academic journal papers to his credit and has attended and presented assessed papers during local conferences in Nigeria. He is highly resourceful, honest, dutiful, and courageous and has been commended by his Head of Department and other senior colleagues in his Department of social sciences for his dedication to duties and ability to work under little or no supervision. Nurudeen is fond of listening to music, watching football and reading. He is an ardent supporter of Chelsea football club.

\section{Ehinola Ebunoluwa Hope}

Ehinola Ebunoluwa Hope was born on the $18^{\text {th }}$ November, 1980 in Owo, Ondo State, Nigeria. She graduated from the Ambrose Alli University, Ekpoma, Edo State, Nigeria with second class upper from the Department of Economics. She is happily married with kids. She was formally an Administrative Officer in Rufus Giwa Polytechnic, Owo and attached to the Directorate of Academic Affairs. She was converted to an academic staff in the Department of Cooperative Economics Management in the same institution through an internal advertisement of 2021. She is a member of Nigeria Institute of Management. She is diligent, committed and dedicated officer who is striving hard to reach the peak of her academic career. Ebunoluwa is fond of meditation, singing and reading.

\section{Ilugbami Joseph Olanrenwaju}

Ilugbami, Joseph Olanrenwaju was born on $14^{\text {th }}$ June, 1965. He has a Bachelor of Science in Sociology in 1997 from University of Ilorin, Kwara State, Nigeria. He also bagged a Master of Science (Msc) in Peace Studies and Conflict Resolution from the National Open University in 2015. He has a Diploma in Small and Medium Scale (Management and Development) from Galilee International Management Institute (GIMI), State of Israel in 2014. Ilugbami, joined the services of the Rufus Giwa Polytechnic, Owo, Ondo State, Nigeria as an Administrative Officer and later converted to academic staff. He is presently a Lecturer 1 in the Department of Social Development. He has published five (5) papers referred and with attendance and presentation of assessed paper during conferences in Nigeria. He has been confirmed membership of Institute of Corporate Administration of Nigeria and Nigeria Institute of Management. He is a dedicated, loyal, committed and resourceful officer of the polytechnic. He has a passion for athletics and table tennis.

@ECRTD-UK https://www.eajournals.org/ https://doi.org/10.37745/ijeld.2013 


\section{Olateru - Olagbegi Olaleke}

Prince Olateru-Olagbegi Olaleke was born on $3^{\text {rd }}$ October, 1970 in Lagos Island, Lagos State, Nigeria and he is a blue blood of Owo Royal Dynasty in Owo, Owo Local Government Area, Ondo State, Nigeria. He holds a Bachelor of Science (B.sc) degree in Political Science and Public Administration with Second Class Upper from the University of Benin, Benin City, Edo State, Nigeria. He also bagged a Master of Science (Msc) degree in Public Administration from the same university in 2017. He joined the services of Rufus Giwa Polytechnic, Owo, Ondo State, Nigeria on $10^{\text {th }}$ July, 2012 in the capacity of Administrative Officer II in the continuing Education Centre (CEC). He was transferred to the Department of Public Administration through an internal advertisement of $17^{\text {th }}$ February, 2013 in the capacity of Assistant Lecturer. He has published 5 papers referred and with attendance and presentation of assessed papers during conferences in Nigeria. He has been confirmed membership of professional body, Chartered Institute of Public Diplomacy Management. He is committed to duties, diligent, resourceful, dedicated, and above all, a great team player and a decent personality. 